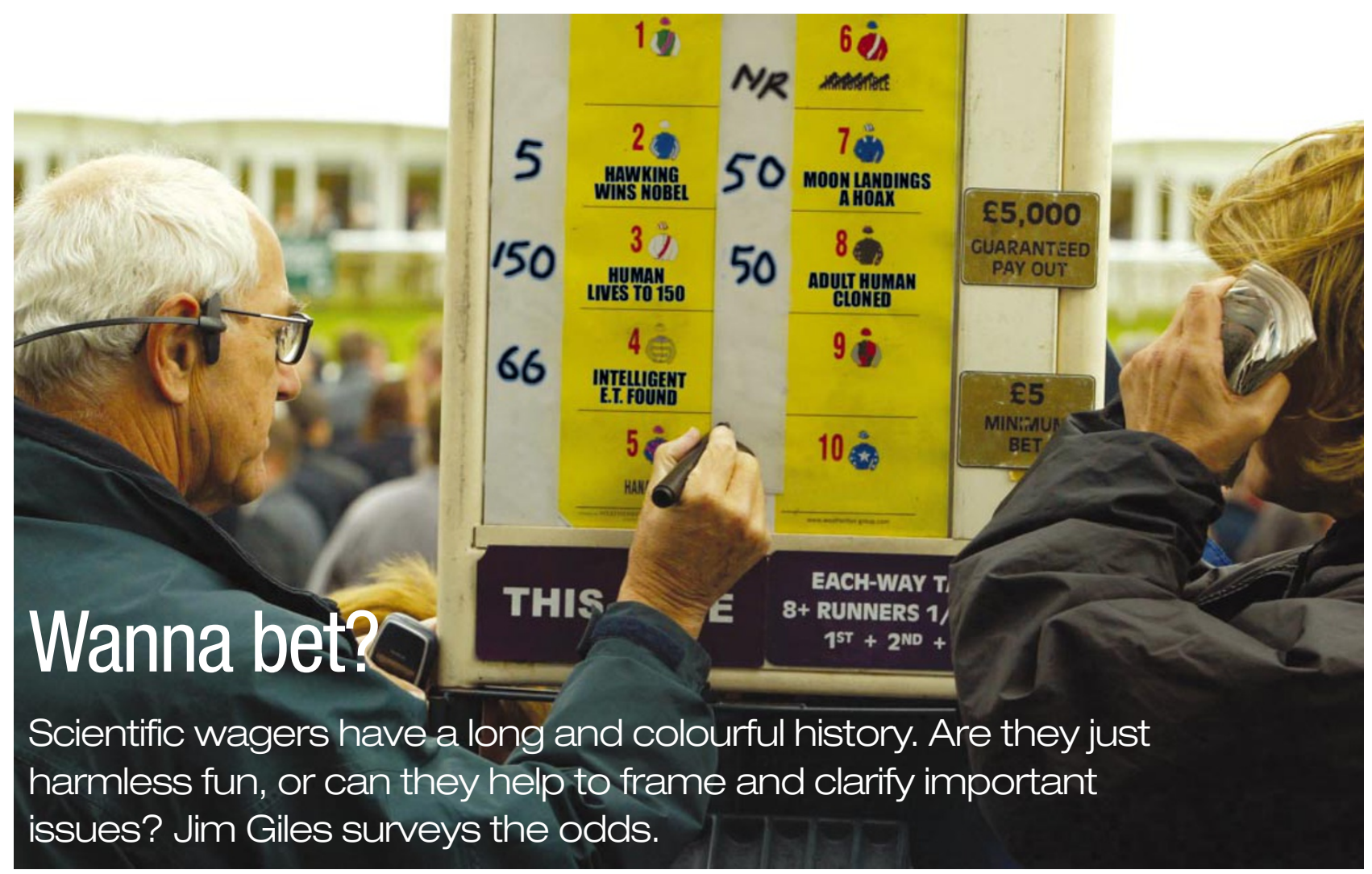

$\mathrm{S}$ tephen was 33 when he made his first bet - an innocent wager with a colleague, just a token prize and professional pride at stake. It was not to be his last. Stephen's career went from strength to strength, but he continued to place wagers. When it comes to making a point about science, Stephen Hawking is a compulsive gambler.

The world's best-known cosmologist is not alone. The history of science is littered with bets, from ill-fated attempts to prove that the world is flat, to numerous wagers over whether various sub-atomic particles exist. A book at the Stanford Linear Accelerator Center in California, for example, records about 35 bets in high-energy physics dating back to the 1980s, many still unresolved. And Cold Spring Harbor Laboratory in New York is running Genesweep, a sweepstake on the number of genes in the human genome.

Genesweep's winner will pocket at least $\$ 750$, and gain the satisfaction of having outguessed a star-studded cast of biologists. But making bets on science has a serious side. By putting their hard-earned cash on the line, wagers encourage scientists to think hard about their arguments and can also attract media attention to otherwise arcane topics. Over the past few years, websites have sprung up to harness these benefits. "A well-conceived bet can frame an issue," claims Kevin Kelly, editor-at-large of Wired magazine, and co-founder of the Long Bets Foundation, which runs one such website. "If it has enough clarity, it can move the subject on."

But scientific wagers have a history of stirring controversy. Take the 1980 challenge laid down by the late economist Julian Simon of the University of Maryland, College Park. Annoyed by claims from environmentalists about the scarcity of natural resources, Simon asserted that the price of five metals would fall by 1990, and challenged dissenters to a wager. Winning the bet, Simon reasoned, would show that these resources are becoming more plentiful, not less so.

Paul Ehrlich, a population biologist at

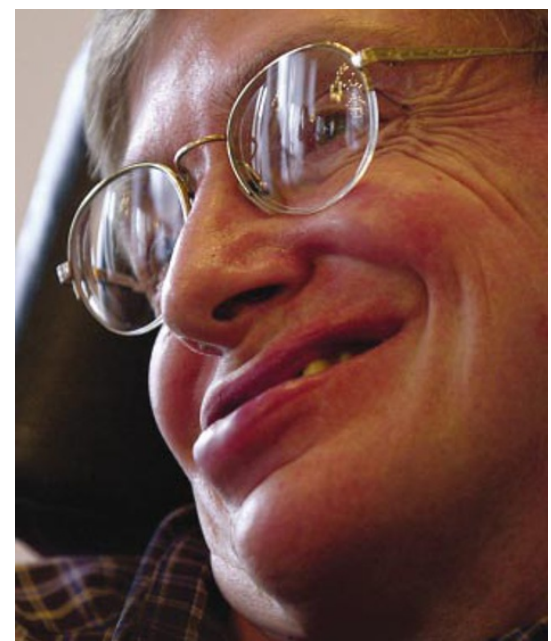

Brief wagers on time: Stephen Hawking is keen to bet on unanswered questions in physics.
Stanford University in California, took Simon on. Together with John Harte and John Holdren, physicists then both at the University of California, Berkeley, Ehrlich agreed to monitor the value of an imaginary portfolio for $\$ 200$ of each of the metals. If the portfolio's value dropped, Ehrlich, Harte and Holdren would pay Simon the difference; if it rose, he would pay them. The metals' value dropped by $\$ 576$ and Ehrlich and his colleagues duly paid up.

Although that bet was settled, the two sides disagree on the lessons to be learned. Some economists use the result to claim that environmental groups exaggerate the problems facing the planet. But Ehrlich maintains that it merely shows that the metals chosen were poor indicators of our exploitation of natural resources. "I regret entering the bet," he says.

Other scientific gamblers have emerged victorious and yet still suffered regrets. In 1870, the British naturalist Alfred Russel Wallace, co-originator of the theory of evolution by natural selection, took up a challenge to prove that the Earth is not flat. John Hamp-

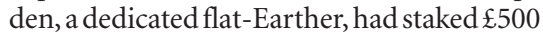
on the question - then a great deal of money. A test, involving a stretch of the Old Bedford Canal, north of London, was agreed on.

Wallace measured the canal's curvature using two markers, separated by about five kilometres and suspended at equal heights above the water's surface. Viewed through a telescope mounted at the same height some 10 $\mathrm{km}$ away from the farthest marker, the nearest 
one appeared to be the higher of the two. An independent referee agreed that this showed the Earth's surface to curve away from the telescope, and Wallace received his money.

But Hampden never accepted the result, and bombarded Wallace and his associates with abuse. In June 1871, he wrote to the naturalist's wife: "If your infernal thief of a husband is brought home some day ... with everybone in his head smashed to a pulp, you will know the reason." Wallace brought and won libel suits, but Hampden was declared bankrupt, leaving Wallace to pay costs. In the end, his winnings were wiped out - and the publicity attracted new members to the flatEarth movement.

Other wagers have produced more fruitful debate. In 2000, Steven Austad of the University of Idaho in Moscow bet Jay Olshansky, a fellow researcher of ageing at the University of Chicago, that someone alive at that time would live to be 150, with their cognitive faculties intact. The two established a trust fund that they estimate will be worth $\$ 500$ million when the bet pays out to one or the other's heirs in 2150.

The wager has been widely discussed in the media. "Bets can be an interesting way to popularize science, as long as those involved make sure that they discuss science when reporters come calling," says Olshansky. He and Austad have been invited to speak in December before the President's Council on Bioethics in Washington. "If our wager contributed to the decision to have this discussion, then it was extraordinarily productive," Olshansky says.

\section{Brought to book}

Hawking's bets have similarly generated media interest - most recently, journalists have picked up on a $\$ 100$ bet made in December 2000 with theoretical physicist Gordon Kane of the University of Michigan in Ann Arbor. Kane asserts that the Higgs boson, the predicted particle thought to give other particles their mass, will be dismilab near Chicago; Hawking says it won't.

So could such publicity, and the way in which bets force both parties to hone their arguments, be harnessed in an organized way? The backers of the Long Bets Foundation think so. The foundation, established last year, aims to encourage people to propose long-term, well-defined bets and to generate discussion about the issues involved. Eleven wagers, worth a total of $\$ 48,000$, have so far been agreed on the foundation's website.

Other bets remain open. Bruce Damer, president of DigitalSpace, an Internet company in Santa Cruz, California, is looking for someone to challenge his assertion that "by 2024, 'artificial' life emerging somewhere out of the soup of human technology will be given a Latin taxonomic name by biologists ... and declared viable for study". Damer has staked $\$ 1,000$, the minimum

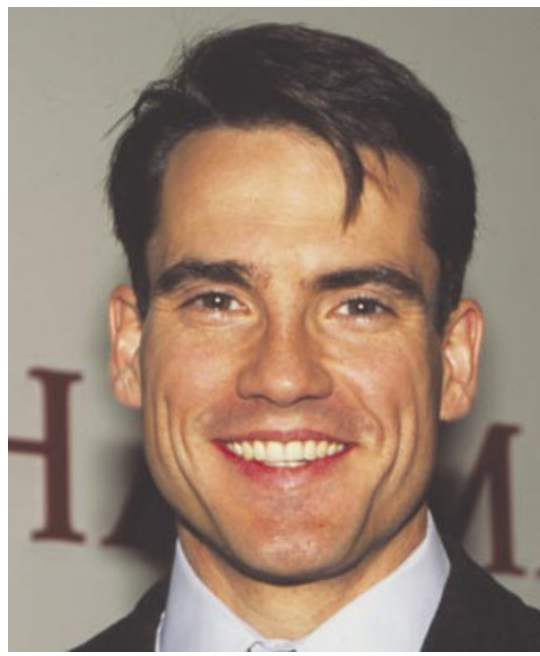

Futures trader: Tom Bell wants to assess scientific theories by having experts invest in 'idea stocks'.

allowed. This is kept in a trust fund and the money generated will be paid to the winner's chosen charity when the bet is resolved.

Kelly believes that the rules encourage responsible predictions. "We feel that there should be some pain in losing," he says. "Normally there is no penalty for being wrong, so people make predictions that are not responsible."

Other groups are trying to develop these ideas further. In the early 1990s, Robin Hanson, an economist now at George Mason University in Fairfax, Virginia, developed the concept of 'ideas futures' - markets that trade shares in ideas. Several versions of his concept, such as the web-based Foresight Exchange, which allows players to trade pretend-money shares in ideas, have been implemented by enthusiasts for market-based solutions.

You might, for example, want to assert that an adult human will have been cloned by 2005 . You would start by 'buying' pairs of coupons in the idea from the market. The

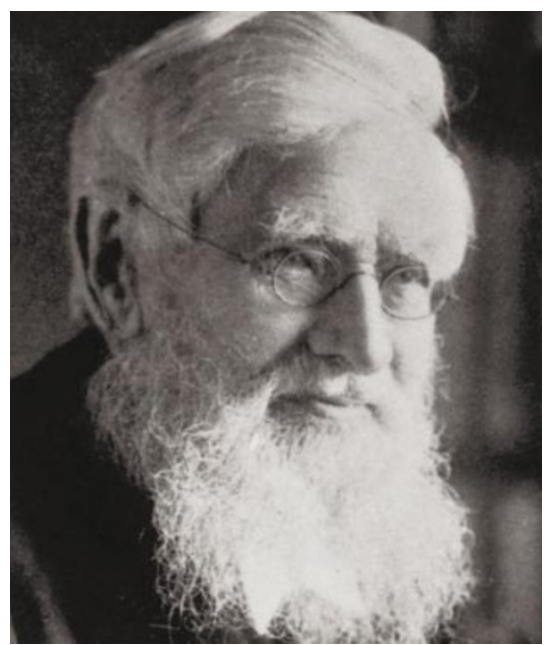

Alfred Russel Wallace won his bet that the Earth is round, but was vilified for years by his opponent.
'YES' coupon pays $\$ 1$ if the claim comes true; 'NO' coupons pay the same if it is false. Confident that a clone will be created, you would retain your YES coupons. Sceptics would buy your NO coupons, believing that they would generate a pay-off in 2005.

\section{A problem shared}

Importantly, the price at which other players are willing to buy coupons indicates how much faith the market has in the idea. The human-cloning claim already exists on the Foresight Exchange. YES coupons were trading at 36 cents as Nature went to press, indicating that the market believes there is a $36 \%$ chance of the claim being correct.

This evaluation may be of limited use, however, as anyone can play the Foresight Exchange and traders are not using real money. But what would happen if an ideas market were to be played by scientific experts using their own cash? According to Tom Bell, a lawyer at Chapman University in Orange, California, such a market would be extremely useful, as the price of shares in a particular idea would provide a snapshot of how the scientific community felt about that issue.

Consider a claim about climate change, such as the size of the expected rise in mean global temperature by 2100 . As long as enough scientists with relevant knowledge played the market, the price should reflect the latest developments in climate research. Policy-makers could use the market as a way of assessing current thinking, free from the bias of industry and activist groups - both of which tend to quote temperature changes at the extreme ends of the spectrum.

Bell is now looking for an institution to host the project, which he has named the Simon Market in honour of Simon's work. But could scientists be persuaded to sink their money into such a market? "If you present it as a scientific experiment then scientists would be eager to try it," suggests Bell. "Scientists also have egos and like money as much as anyone else." His proposal is currently being considered by the Mercatus Center, a public-policy, law and economics offshoot of George Mason University.

Whether the ideas of Bell and the Long Bets Foundation will sway public debate or merely provide entertainment remains unclear. But while you're totting up the odds, there's still time for visitors to Cold Spring Harbor to enter Genesweep, before the final figure is announced next year. Our tip: 31,789 genes.

Jim Giles is Nature's associate News and Features editor. Genesweep

\section{www.ensembl.org/Genesweep}

Long Bets Foundation

www.longbets.org

Foresight Exchange

www.ideosphere.com

The Simon Market

www.simonmarket.org 